\title{
64 anos de magistério de dona Emília Rodrigues (1863-1946)
}

Em março de 2007, publicamos no DN Educação do Diário de Natal um artigo de título-Mulheres educadoras, mulheres professoras, mulheres notáveis norte-rio-grandenses. Nesse artigo, realcei o Rio Grande do Norte com uma atuação excepcional de mulheres no magistério, pouco perceptível no começo do seu povoamento; mas sempre extraordinária. Entre 1827 (data da aprovação da Lei, de 15 de outubro de 1827, celebrada como a norma que institucionalizou a educação primária no Brasil) e 1900 (último ano do século XIX| foi notável a quantidade de professoras de educação escolar primária no Rio Grande do Norte. A Sessão Documento homenageia uma das grandiosas mulheres educadoras dona Emília Rodrigues (nascida no ano de 1863 em São José de Mipibu) - professora de educação escolar primária em várias cidades no interior do Rio Grande do Norte, dentre elas Macaíba, desde o ano de 1882. Em 1946, com 83 anos de idade permanecia ensinando, quando o Inspetor de Ensino F. Rodrigues esteve fiscalizando a "Escola de dona Emília". Entusiasmado com o seu trabalho pedagógico, escreveu no jornal "A República" (Natal, 6 de julho de 1946) a matéria abaixo publicada.

Marta Maria de Araújo

Universidade Federal do Rio Grande do Norte

\section{4 anos de magistério}

Dona Emília Rodrigues é professora, na cidade de Macaíba, desde 1891. Nasceu, em São José do Mipibu, em 1863. Ignora, porém, dia e mês de nascimento. Aí fez os seus estudos primários, com a professora Florência Anália Cesar de Albuquerque que, esposa do capitão Hermano Clementino Cesar de Albuquerque, que também havia sido professor. Completando os seus 12 anos, deixou os estudos, para obedecer ao "regime" da época, "sendo uma das meninas mais adiantadas da escola de D. Anália"... Afirmou-se dona Emília Rodrigues que era, assim, no meu tempo: uma menina só tinha direito de frequentar aula, até 12 anos. Coisas interessantes que já vão longe e que não voltarão mais... 
Sentindo vocação para ensinar, 7 anos depois, animada pela sua ex-professora, saía da cidade, para "as várzeas do Arenã", onde começou a lecionar, a 500 reis, por menino, isto no ano de 1882. Daí, saiu, no ano seguinte, para Santo Antônio do Salto da Onça, hoje Padre Miguelinho, onde permaneceu, cerca de um ano, aproximadamente, saindo para Araruna (Paraíba). De Araruna voltou ao ninho antigo, São José de Mipibu, mudando-se, em seguida, definitivamente, para a cidade, que teve a suprema alegria de servir de berço a Auta de Souza e a Augusto Severo (Macaíba).

Chegando, instalou sua escola e, nas horas vagas, dava aulas, em domicílios, numa faina, incessante de todos os dias, alimentada pela chama vultosa desse ideal sublime que não deslustra, em nada, os [ensinamentos] de Pestalozzi: o ideal de educar e de instruir.

Dona Emília foi sempre, como está sendo ainda, mesmo no crepúsculo da vida, com 83 anos de idade, uma dedicação a toda prova, um modelo modesto de trabalho honesto, em prol da instrução do povo; enfim, uma operária incansável na construção do grande edifício da Pátria, que abençoará o seu esforço e bendirá o seu sacrifício, depois de dar-the, perante o altar da Gratidão e do Bem, a unção dos santos óleos da religião e do Civismo e a coroa de louros da consagração nacional.

242 E nem poderá ela deixar de merecer menos disso, pelo apostolado, longo e penoso, que vem cumprindo, com a alma dos eleitos e o espírito dos predestinados, em favor da libertação dos escravos da ignorância. Visitando em objeto de inspeção, a escola de dona Emília, fiquei satisfeito da organização e da ordem que ela imprime a tudo, notadamente na parte que diz respeito a disciplina. Apesar da idade, a MESTRA ainda lê sem óculos, fala alto e dorme a noite toda...

Sua sala de aula é bem limpa, arejada dispondo de um mobiliariozinho tosco, mas completo, e de um bom relógio, que comprou, no Recife, por 25\$000 Reis, em 1911. Dona Emília conversa, com equilíbrio de linguagem, e suas palavras são incisivas, assim: "Só deixo de ensinar, quando Deus quiser." "Meu maquinismo é muito forte ainda." Seu exemplo deve servir de forte estímulo a todas as professoras brasileiras, principalmente aquelas que não sentem, na alma, os eflúvios da "virtude ensinante" do pensamento e do sentimento do próprio Pestalozzi. Que as alteridades do Estado, e particularmente, do município de Macaíba, não esqueçam quem há trabalhando, tanto, sob a cúpula da obscuridade, por um Brasil maior e mais digno do conceito das nações civilizadas do mundo. 


\section{Referência}

ALVES, F. Rodrigues. 64 anos de magistério. A República, Natal, p. 4, 6 jul. 1946. (Coluna Educação e Ensino).

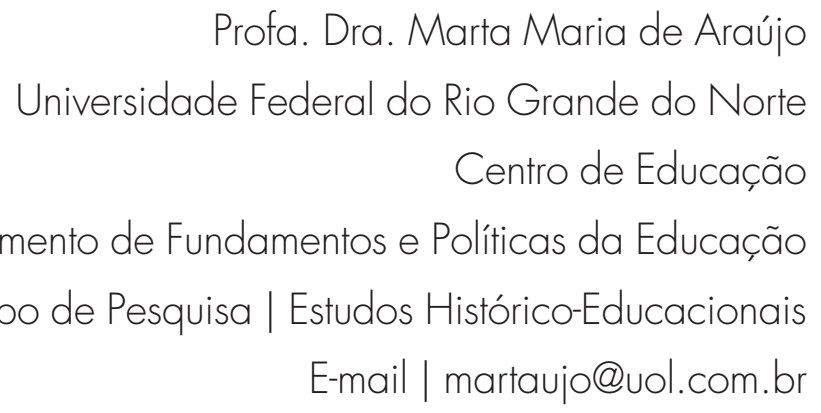

